\title{
Britain in the Seventies - Our Unfinest Hour?
}

Les années 1970- le pire moment de l'histoire britannique?

\section{Kenneth O. Morgan}

\section{(2) OpenEdition}

\section{Journals}

Electronic version

URL: https://journals.openedition.org/rfcb/1662

DOI: $10.4000 /$ rfcb.1662

ISSN: 2429-4373

\section{Publisher}

CRECIB - Centre de recherche et d'études en civilisation britannique

\section{Electronic reference}

Kenneth O. Morgan, "Britain in the Seventies - Our Unfinest Hour?", Revue Française de Civilisation Britannique [Online], XXII- Hors série | 2017, Online since 30 December 2017, connection on 16 February 2023. URL: http://journals.openedition.org/rfcb/1662 ; DOI: https://doi.org/10.4000/rfcb 1662

This text was automatically generated on 16 February 2023.

\section{cc) $(1) \ominus$}

Creative Commons - Attribution-NonCommercial-NoDerivatives 4.0 International - CC BY-NC-ND 4.0 https://creativecommons.org/licenses/by-nc-nd/4.0/ 


\title{
Britain in the Seventies - Our Unfinest Hour?
}

\author{
Les années 1970- le pire moment de l'histoire britannique?
}

\author{
Kenneth O. Morgan
}

1 In popular recollection, the 1970s have gone down as the dark ages, Britain's gloomiest period since the Second World War. It may be that the aftermath of the Brexit vote in 2016 will herald a period of even greater crisis, but for the moment the sombre seventies, set between Harold Wilson's 'swinging sixties' and Margaret Thatcher's divisive eighties, stand alone. They began with massive trade union stoppages against Heath's Industrial Relations Act. They continued with the financial crisis of the IMF and the random atrocities of the Irish Republicans. They ended with the 'Winter of Discontent' when unparalleled strikes, official and unofficial, revealed a country 'as governable as Chile' in the populist view of one US politician, and reduced the Labour prime minister, James Callaghan, himself an old trade union official, to a paralysis of despair. He felt, as he told Ken Stowe, his private secretary (and later me) that he had 'let the country down'. The idea of 'dark ages' is indeed literally appropriate. Recollections of the seventies are coloured by memories of a public blackout, reminiscent of the second world war during the blitz, without the compensating feeling of national heroism and historic endurance. The earlier years of the decade featured not only many strikes by the engineers and electrical workers, but Edward Heath's catastrophic three-day week in response to the miners' strike of 1974 when London's major thoroughfares were cast into darkness, shops and restaurants were unlit and gloomy, public television services were suspended for several nights a week, and suburban families ate their sombre dinners at home not very romantically with the light of such spare candles as shopkeepers still had available.

2 This popular gloom was echoed, indeed reinforced, by historians and political commentators. In the late seventies, there was a flood of pessimistic literature, particularly from Americans, on the state of the nation - The Future that Doesn't Work: Social Democracy's Failures in Britain (1977), The Politics of Economic Decline (1979), Britain: Progress and Decline (1980), and, most evocative of all, Isaac Kramnick's Is Britain Dying? (1979). A serious academic account of the IMF crisis in late 1976 was entitled, somewhat 
absurdly, Goodbye Great Britain. ${ }^{1}$ Historians gave their books titles which heavily featured words like 'Decline', 'Downfall' and 'Eclipse', seeing the roots of disaster perhaps as far back as the 1870s, perhaps even in Britain's very existence as a self-contained island country over the centuries. It seemed the bleakest time since the mass unemployment of the inter-war years. Everything was going wrong. There was turmoil in industry and a collapse of public services from schools to cemeteries, a growing mood of very un-British violence from the IRA to football fans on the rampage to battered wives, there was ethnic tension, the population was ageing and the birth-rate falling, English football had slumped since the World cup victory of 1966. Its male tennis players were near-useless, and its cricketers humiliated by the Australians and the West Indians. The most appropriate Latin tag for an unduly classically-educated people was sunt lacrimae rerum the Tears of Things. At another time of national gloom, therefore, forty years on, it is appropriate for the historian to examine how valid these depressing verdicts on the United Kingdom really were. After all, variously during the Thatcher years and the heyday of New Labour after 1997, Britain seemed to bounce back impressively and manifest a new self-confidence and buoyancy. The sick man of Europe became for some years its social and economic front-runner, leaving France and even for a time Germany trailing in its wake. Were the dark ages an exaggerated fabrication of excited journalists and ill-disposed foreigners? Or did the seventies uncover something fundamentally wrong about this ancient people which survives to diminish its authority and restrict its vision down to the present day?

\section{The Down Side}

3 The negative aspects of Britain in the seventies, on which commentators focussed, were essentially four. These were conflict and class war in industry, a sharp downturn in the economy, a flight to extremism in political life, and a rise in public and domestic violence. Without doubt, each of these revealed a new pattern of internal vulnerability not experienced previously, and a marked contrast with the stable social democracy that the United Kingdom had appeared to be since the second world war, both under Labour's welfare democracy under Attlee after 1945 and Wilson after 1964, and the thirteen years of emollient 'one-nation Toryism' in between. Now there were new challenges to which a post-imperial, once-great power seemed unable to respond.

4 The social conflict in industry, certainly, was on a scale and of a character not experienced since the days of the Triple Alliance, Black Friday and the General Strike between 1919 and 1926. It is true that warning signs of future conflict had been evident in the later sixties. The Donovan report of 1968 illustrated how the internal structures of leadership in the unions had been changing in the sixties with power increasingly passing to shop stewards like 'Red Robbo' (Derek Robinson) in Longbridge and Alan 'the Mole' Thornett in the Cowley car plant in Oxford during unofficial strikes. National collective bargaining was becoming localised which gave militants on the shop floor more power. Barbara Castle, backed by the prime minister, Harold Wilson, had tried to deal with this by legislation but her 1969 Industrial Relations Bill was strongly opposed by the unions. It met with its nemesis in Cabinet, the main opponent being no less than the Home Secretary, Jim Callaghan. But the turmoil provoked by Heath's 1971 Industrial Relations Act was of a quite different order. It was a dangerous attempt to apply legal sanctions to industrial relations which had been governed by voluntary collective bargaining since the 
1906 Trades Disputes Act, a policy which the Donovan report had previously supported. The irony was that the unions had carefully observed the terms of the Act - and yet the strikes went on. Furthermore, the trade unions were now primed for battle as never before. Their membership had been rising fast, reaching a record 13,498,000 in 1979, growing spectacularly amongst white- collar workers, with unions like NUPE and NALGO recruiting strongly amongst local government workers and amongst groups such as health service workers and schoolteachers. The unions now had immensely powerful national officials like Jack Jones, secretary of the mighty Transport and General Union, with well over a million members. Frightened journalists wrote of 'The Emperor Jones' and of the 'terrible twins', Jones and his associate Hugh Scanlon of the Engineers. Heath's Industrial Relation Act of 1971 led to the largest trade union protests for two generations, while a hitherto unknown public official called the Official Solicitor was called in to release some trade officials, the so-called 'Pentonville Five', from gaol. Worse still followed with two national coal miners' strikes in 1972 and the beginning of 1974, the first such since 1926 . They were solidly backed by the TUC's general secretary, Vic Feather. The first led to a total surrender to the wage and bonus demands of the miners ( $a$ surrender duly noted by the government's Minister for Education, Margaret Thatcher). The second in January 1974 led to a national state of emergency, the three-day week and a general election called by Heath on the theme 'Who Governs Britain?' The answer appeared to be the unions since Heath was defeated and had to resign.

5 The union troubles, however, continued to mount up alarmingly under Labour. Wilson and Callaghan had concluded a so-called 'social contract' with the TUC under which the unions would supposedly observe wage restraint while legislation sympathetic to their wishes went through. The minister responsible for industrial relations was now Michael Foot, an old left-winger determined to give way to the unions on virtually everything, including the closed shop: he did, however, restore a measure of order to relations with the unions more on the lines intended by the Act of 1906, the so-called Magna Carta of Labour. ${ }^{2}$ But strikes continued, many of them unofficial, and wage claims mounted, driving the level of price inflation up to almost 30 per cent. All manner of workers were now engaged including key groups not previously considered as a threat such as the water workers. Some employers made matters far worse by an intransigent anti-union attitude such as in the Grunwick photo-processing works in North London where the farright owner sacked a number of Asian women workers who were members of unions. This led to daily violent confrontations between police and up to 20,000 workers outside the Grunwick plant, and a new sense of class war between the unions en masse and rightwing journalists and commentators. There was talk of private anti-union groups being prepared for a coup armed by an eccentric extremist called Colonel Stirling, and General Walker's 'non-party militia'. A sense of potential civil war loomed in England's green but no longer pleasant land.

6 The worst of the class war came, ironically, under the premiership of James Callaghan, the old trade union official who had led the opposition to Barbara Castle's bill of 1969 in Cabinet. Fanned by a background of lagging pay increases and reviving price inflation, there erupted a massive series of industrial disputes that lasted from late October 1978 to the spring of 1979. These were random, often quite unco-ordinated affairs. While many workers could be classed as low-paid, many of the strikers, such as oil-tanker drivers and power workers, were not and their actions added to the inflationary pressures on their poorer comrades. There were large unions on strike like the Transport and General 
Workers (led now, not by Jack Jones who had retired, but by a weak former shop steward called Moss Evans). But there was also a wide array of almost nihilistic local strikes which impacted directly on the public. Striking dustmen meant that putrid rubbish bins were not collected and emptied, children were kept out of school by striking school caretakers, hospital wards were closed by striking health workers and patients died. In one especially notorious episode, Liverpool grave-diggers went out on strike. A Cabinet minister, Harold Lever, gloomily observed, 'Let the dead bury their dead'. ${ }^{3}$.The government seemed paralysed by the extent of the strikes and stoppages. In January and February 1979, almost 30 million working days were lost, more than three times the whole of the previous year. On the worst day, 22 January 1979, $1.5 \mathrm{~m}$. public sector workers did not turn up for work. Callaghan, slumped in anomie, could offer little other than an almost meaningless 'St. Valentine's Day agreement in February. The government failed to call a state of emergency which ministers like David Owen wanted. The strikes went on, at a diminished pace, until the minority Callaghan government fell from power at the general election in May.

7 Of course, many commentators gave exaggerated, politically prejudiced, verdicts on the Winter of Discontent. Not all workers were on strike all the time. Many of them were very brief and unco-ordinated. Some of the wage claims, including by the miners, had much justification at an inflationary period even if high wage settlements made that inflation worse. Many were provoked by insensitive and right-wing employers with poor management skills. But it would be absurd to deny that something very unusual and alarming was taking place' A total of 29,474,000 working days were lost in 1979, easily the worst since 1943 (the next worse were also in the seventies, the second highest in 1972 with 23,909,000 and the third 1975 with 14,750,000). In all, 4,583,000 workers were involved in 1979 and there was a massive loss of production. ${ }^{4}$ The psyche of the country was deeply shaken. Later, the unions, especially after their defeat in the $1984-5$ miners' strike, were to suffer a steep decline: their membership slumped from 13 million to just over 5 million; their power has been gravely undermined by legislation; their allies in the Labour Party were to be out of power for eighteen years. The unions had refused to move away from their traditional, adversarial, 'them and us' class attitudes. Proposals for industrial co-determination contained in the 1976 Bullock report had failed because the union leaders had no wish to become bosses under the capitalist economic order. The resultant folk memories of 'he enemy within' were kept warm by Mrs. Thatcher. At the Conservative conference she recalled the bad old days when the unions reflected the leftwing dogma of a socialist government. 'Do you remember the Labour Britain of 1979? It was a Britain in which leaders held their members and our country to ransom. ${ }^{15}$ The unions' behaviour had destroyed their role in a corporate Britain going back to Ernest Bevin during the war. The ancien regime was over.

Closely intertwined with the industrial conflicts of the seventies, of course, was the decline of the economy. Despite repeated balance of payments problems and the forced devaluation of the pound in 1967, the Labour government of the sixties kept things reasonably stable. Employment was high; inflation under control. Economic historians wrote of a 'golden age' of the economy which lasted from 1945 to 1973. However, the Labour years had been one of frequent crisis, with frequent recourse to bailouts from the US Treasury. The plan for four per cent a year economic growth had manifestly failed, and the growth rate in $1964-70$ had, if anything, been below that of the previous six years under the Tories. The new department supposed to promote growth, the 
Department of Economic Affairs under George Brown had been humiliatingly abolished. From the early seventies, the dark clouds rolled in.

The old nostrums, those of Keynes and Beveridge, which had governed social and economic policy since the war under both major parties, now seemed no longer valid. Increasingly, economic writers suggested that Keynesianism, with its expansionary pump-priming economics and positive use of the deficit in finance, was proving out of date. It paid insufficient attention to the global economy and to inflation (in fact, an inaccurate account of Keynes's own views). For many decades, following Keynes, governments had regarded a return of pre-war unemployment as the main danger to be avoided. Now economists, especially in the United States, urged that inflation not unemployment was the major evil to be identified, and this should be checked through strict controls of the money supply. This was the burden of a growing number within the Conservative Party, attracted by the monetarist doctrines of the Chicago economist, Milton Friedman. Particular evangelists for this viewpoint were the maverick rightwinger, Enoch Powell, and a more recent guru, Sir Keith Joseph, and it was also voiced by a think tank like Ralph Harris and Arthur Seldon's Institute of Economic Affairs, deeply committed to the neoliberal doctrines of the venerable Austrian guru, Friedrich von Hayek. ${ }^{6}$ Nor was the critique of Keynesianism confined to Conservative ranks. Peter Jay, son-in-law of the prime minister Jim Callaghan and son of a famous socialist theorist, Douglas Jay, hammered out the same message as financial columnist of The Times. With the theoretical basis for analysing weaknesses of the British economy discredited, politicians found themselves in the unknown without a map and without a compass.

Throughout the seventies the endemic structural problems of Britain's economic performance plagued every government and provided painful experiences for working citizens. The Heath government which took office in June 1970 had won the election on a starkly anti-state manifesto, designed to curb central planning and to stimulate the private sector with tax cuts and other measures. Long before it fell from power, it was clear that its economic policies were a total failure. In addition to failing to secure a prices and incomes agreement with the trade unions, its Chancellor, Anthony Barber proved to be highly incompetent and his supposed 'dash for growth' was having precisely the reverse effect and leading to a property boom and huge inflation. In addition, the government had the misfortune to be in power at a time when the outcome of the ArabIsraeli war of 1973 led to a massive oil price inflation with the nation's balance of payments suffering badly. Heath, who had totally reversed the Selsdon Park programme in office, was now replaced in 1975 as Tory leader, by Margaret Thatcher, a far more committed supporter of monetarism with a particularly close relationship with Sir Keith Joseph. But it was now Labour which had to bear the burden of economic decline. Denis Healey, Labour's powerful Chancellor from March 1974 had to grapple with a new phenomenon that of 'stagflation' with inflation and unemployment both rising at the same time. ${ }^{7}$ Inflationary cost-push pressures at home from aggressive unions made his dilemma all the worse. In 1975, with inflation approaching 30 per cent, his policies seemed about to collapse in ruins but he was rescued by Jack Jones who committed the unions to a flat-rate wage increase of $£ 6$ a week - a proposal which, of course, was also strongly egalitarian.

11 But by the autumn of 1976 the British economy seemed at a critical point. Notable was the fact that the Labour government was giving sops to monetarism itself. Healey began the policy of privatizing public assets starting with Burmah Oil, and of applying cash limits 
and other monetary targets to public spending. More startling still, Callaghan shook the 1976 party conference by telling them that 'you can no longer spend your way out a recession' in a passage of his speech written by his son-in-law, Peter Jay. ${ }^{8}$ But the inexorable financial problems of the British state continued. There were runs on sterling and talk of a further devaluation. Tense discussions were now conducted with the International Monetary Fund about the kind of monetary package that would be socially acceptable. Callaghan, who well recalled from his earlier career the downfall of Ramsay MacDonald, another Labour prime minister who was forced to talk to international bankers in 1931, kept his Cabinet in continuous session on a collective basis. In the end, he managed to get his way, just, against both Keynesian expansionists like Crosland on the right, and left-wing anti-capitalists like Tony Benn on the left. In the end, the IMF granted the government $\$ 3.9$ billion credit as against a $\$ 2.5$ billion cut in domestic expenditure. For the next eighteen months, the government did much better. Douglas Jay wrote that it was a rare administration that sharply reduced inflation and cut unemployment at one and the same time, a rare double achievement. ${ }^{9}$ But in the end the pressures of the 'winter of discontent' were overturning the government's policies once again, and when Callaghan left office in May 1979 the economic warning signs were all too visible. Britain's standing as the sick man of Europe seemed all too clearly confirmed.

There can scarcely be any argument that Britain's economic standing was severely weakened through the seventies, by global issues of inflation, and by industrial disorder at home. The country suffered and governments were hapless victims. The partial recovery in 1977 - 8 suggests that there was still resilience. One fortuitous salvation was floating the pound, that is, the ending of fixed exchange rates, surviving from the 1944 Bretton Woods agreement, in 1972. While this ate into the exchange value of the pound, it means that it was no longer a reserve currency and the reserves less buffeted about by global pressures. More practical and visible was the fact that in later seventies, oil from the North Sea was starting to come through after 1975 to the immense benefit of both the balance of payments and inflationary pressures. Europe's sick man seemed likely to become as oil rich as countries in the Middle East, perhaps even to enter OPEC. But this would only really assist the economy if the gains were devoted to investment and modernization, and British internal economic relations were to become less disorderly. As Margaret Thatcher entered 10 Downing Street in May 1979, somewhat vacuously citing blessings from St. Francis of Assisi, this all seemed a long way off.

13 Another alarming feature of British experience in the seventies was the polarization of its politics. Since the second world war, despite the harshness of party disputes, there was relatively consensual aspects to political life. At times, there was talk of a possible coalition government under someone like Callaghan. In the fifties, the journals invented a composite figure, 'Mr. Butskell', part Mr. Butler, a one-nation Tory, part Mr. Gaitskell, a Labour centrist. ${ }^{10}$ Even in the sixties, Harold Wilson and Edward Heath did not seem that far apart. The mixed economy, the welfare state, full employment, decolonization in the old empire, collaboration with the US in overseas affairs but steadfast resistance to involvement in war, as in Vietnam, were common to all the major parties. Europe was a divisive issue, but the Conservatives got the country into the Common Market in 1973 and Labour confirmed it through the new device of a referendum in 1975. The tiny Communist party faded away while British fascism had little substance in the first place.

In the seventies, it all changed and turned very sour. In both the Labour and the Conservative parties there were sharp moves to the extremes. Worryingly for both 
parties, two-party politics in which the big parties aggregated up to 90 of the vote for themselves, was giving way to a more fluid system in which the Liberal Party showed a brisk revival under Jeremy Thorpe, challenges threatened the Labour ascendancy in both Scotland and Wales from the nationalist parties, and individual revolts against their party's leaders were more numerous, as with Dick Taverne in the Labour Party in Lincoln and Enoch Powell in the Conservatives who migrated to North Down in Ulster. British politics seemed pluralist, almost unrecognisable.

Amongst the Conservatives, the major transformation was that the 'peasants' revolt' identified with Margaret Thatcher when Heath fell as party leader, pushed the party away from One-Nation traditions to the neoliberal, free-market right. The main leaders throughout the seventies - men like Carrington, Whitelaw, Pym, Prior, Gilmour and Walker - were still recognisably of the centrist tradition and not far removed from their Labour opposites. But pressures in the party were moving against them. A particularly influential figure was Sir Keith Joseph whose well-publicised opinions became a focus for strongly anti-statist views on the economy and suspicion of colonial and other immigration in social policy. Margaret Thatcher was a vehement disciple of the monetarist, neoliberal doctrines of Hayek. She became a prominent member of a new right-wing think-tank, the Centre for Policy Studies: its leading figure, the sternly monetarist Sir Alfred Sherman became an important adviser. These new-style Conservatives more than carried the fight to the socialist enemy. ${ }^{11}$ They recruited from them, too. Former Labour ministers like Reg Prentice and Lord Chalfont, an eloquent younger Labour ex-MP, Brian Walden, all subscribed to the vibrant new creed. They were not yet dominant. When Mrs. Thatcher started her premiership in May 1979 the great bulk of her Cabinet were moderate One-Nation Tories of the old school, following the path of party leaders from Butler to Heath. By the end of 1981, the great bulk of them had gone and the assault on Keynesian economics was being pursued apace. The neoliberals had taken over the ship. It was entryism on the grandest and most audacious scale.

In the Labour Party, entryism of a quite different kind was under way. The disillusion with Labour policies, including the failure of planning, had generated major changes in the party in the years of opposition between 1970 and 1974. The evasions and compromises of Wilson's leadership had generated widespread discontent both in the constituency parties and the trade unions. The grass-roots, discontented with a complacent, inbred party apparatus in many of Labour's heartland constituencies, moved sharply to the left. They found their inspiration in Tony Benn, a centrist, pro-Europe, proNATO Minister of Technology under Wilson, who now became the voice of socialist revolt and a charismatic figure for the rank and file. By 1972 his outlook had changed completely. Allied to far-left colleagues like Eric Heffer and the veteran Ian Mikardo, he was an articulate, dangerously charismatic leader of the constituency far left. He was notably unfussy about his political allies, who included key leaders, Trotskyist or even Stalinist, later prominent in the Militant Tendency, directing their fire against what seemed to be the tired old party leadership. One of them, in Haringey in North London, was the future leader of the party forty years on, Jeremy Corbyn. They elaborated a programme that rejected almost every major part of Labour's programme. They wanted higher taxation, extensive further nationalization, the imposition of central planning agreements on private industry with private co-operatives in specific plants, unilateral nuclear disarmament, 'troops out' in Northern Ireland, and the no British membership of the European Common Market. Meetings of the party conference, even more of the party 
executive, became divisive and highly contentious, especially when left-wing officials like the party secretary Ron Hayward were appointed. In the later seventies, with a violent upsurge in the constituencies, encouraged by Benn, hostile to any anti-inflation policies or dealings with the IMF, party conferences became a nightmare. With their demand for an enclosed siege economy at home, and a 'socialist foreign policy' overseas, the Labour Party rank and file, like Stalin, was pursuing socialism in one country.

More dangerous were the mass trade- union leftists who turned to radical political action, stirred by the industrial revolt against wage restraint. Union power made itself felt throughout the party. No longer, as in the old days of leaders like Arthur Deakin of the Transport Workers were the unions loyal and docile followers of the 'labour alliance' with the political party. Many of their leaders were on the far left willing to ignore the usually more moderate views of the rank and file, as with Alan Fisher, secretary of NUPE, strongly entrenched in local government, or Ray Buckton of the engine drivers' union, ASLEF. A rising young militant in the Miners' union Arthur Scargill of the Yorkshire men, famous for his flying pickets and 'the battle of Saltley Gates' during the 1972 national strike, was effectively a Communist. Many of them, like Moss Evans of the TGWU seemed to have little understanding of political processes at all, and, despite the 'social contract' concluded with the Labour Party in 1973, little concern for how their actions might affect the future election of a Labour government. It was the world of industrial relations, or rather industrial confrontation, that interested them. As the old Yorkshire leader Ben Smith, had once observed, 'On t' field, that's t' place'. Allied to the Bennites and Militants in the constituents, they were pushing the party to a place far to the left of the Bevanites in the fifties. After all, Bevan's followers claimed to be extra-parliamentary. The new, hard left was enthusiastically anti-parliamentary.

With the Tories sliding to the neo-liberal right and the Labour rank and file pushing towards the Marxist hard left, many worried about the political culture of their country. The old landmarks of post-war Britain seemed to be disappearing. Concern was most memorably expressed by Roy Jenkins, now president of the European Union, in his Richard Dimbleby radio lecture of 1979. He quoted W.B Yeats's famous poem on the 1916 Easter Rising in Dublin. 'The Centre cannot hold. The best lack all conviction and the worst are full of passionate intensity'. It was a despairing cry from the most important voice of civilised moderation. It was in two years' time to lead to a major split in the Labour Party and the founding of the Social Democratic Party, headed by Jenkins himself. It echoed the gloomy message of Sir Nicholas Henderson when he moved to the Washington embassy in June 1979. He had commented how the great international power of 1945 had shrunk in power and authority, with economic weakness abroad and social division at home. He linked this to Britain's long failure to involve itself in Europe. ${ }^{12}$ After the May 1979 general election, many observers wondered whether some kind of centrist government of national unity would emerge in a political world dominated by Thatcherites on the right and Bennites on the left. The Centre holding became a major theme after the gloomy events of the seventies.

Finally, it seemed not only to be time of industrial conflict, economic decline and political extremism, but a period of violence. In many areas, Britain, a peaceful, stable country which had not known serious internal conflict since the civil wars of the seventeenth century, seemed to be emerging in a harsh, even brutal, light. The most visible indication of this came with terrifying events in Northern Ireland. After the relative optimism felt about the civil rights movement in 1969 - 70, when Callaghan handled Ulster at the Home 
Office, the advent of the Conservatives, with Reginald Maudling now dealing with the province, saw things go rapidly go downhill. A relaxed easy-going man in manner (with suspect relations with the business world), he reacted to the increasingly alarming events in Northern Ireland with remarkable severity. ${ }^{13}$ After the conciliatory, constructive policies in Northern Ireland pursued by Callaghan under the Labour government, Maudling resorted to internment without trial, to trying suspected terrorists in the juryless Diplock courts, and to harsh conditions for those in custody in Long Kesh prison. The worst of all came on 30 January 1972, 'Bloody Sunday' in popular recollection, when the Parachute Regiment opened fire on Catholic civil rights demonstrators on the streets of Londonderry, and 13 civilians were killed. A young Nationalist MP, Bernadette Devlin ran up to Maudling in the Commons chamber, slapped his face and called him 'a murderous hypocrite'. It took over 40 years for the course of events finally to be condemned when the Saville inquiry revealed the full horrors, during David Cameron's premiership, but the effect on Northern Ireland was appalling. Both the Protestant majority and Catholic nationalists moved to the extremes. Amongst the Ulster Unionists, leadership passed to the Democratic Unionists headed by a ferociously anti-Catholic demagogue, the Revd. Ian Paisley, challenging the moderate reformist premier, Brian Faulkner, at every turn. On the Nationalist side, the initiative was seized not by the constitutional SDLP but by Provisional Sinn Fein, intimately linked to the violent men of the IRA. Heath had to wind up the Northern Irish government at Stormont and to impose direct rule from Westminster.

The consequences both in Northern Ireland and parts of mainland Britain were horrifying. There was a rising tide of violence, assassinations, bombings and casual shootings, over the next few years. Relations between the occupying British army and the resident Nationalists amounted to a state of war. Parts of Belfast, like the Catholic Falls Road and the Creggan estate, became almost ungovernable. A power-sharing agreement concluded at Sunningdale in December 1973 was soon made redundant. When Labour returned to government at Westminster, it found itself immediately confronted in May 1974 by a general strike called by the Ulster Workers' Council. With broad support amongst Ulster's Protestants, Wilson's government had simply to surrender. Violent events now multiplied in Britain itself, with the atrocious murders of civilians in Birmingham, Guildford and other places, Years after these horrors, Irish anger was inflamed by evidence of police irregularities in the trials and of wrongful arrests which took years to reverse. Another tragedy was the murder of the right-wing commentator, Ross McWhirter, a strong critic of the IRA, at his home. Queasy American tourists refused to visit London as the city was deemed unsafe; Londoners, hardened by old memories of the blitz, were more resilient. In the final two years of the Labour government, 1977 - 79, the experience of Northern Ireland was desolate. The Secretary for Northern Ireland now was the Yorkshire miner, Ropy Mason, a strong partisan of the Unionist cause, while relations with the Republic of Ireland rapidly deteriorated during its Fianna Fail government under Jack Lynch, the old party of Eamonn de Valera. There was no advance on any front now. To many in Britain, these horrifying events in Northern Ireland were the product of an alien society, so different from the tranquil continuities of mainland Britain. But they could not fail to leave their legacy of violence there too. Apart from the atrocities occurring on a regular pattern on the streets of English towns and cities, they served to make the United Kingdom a more authoritarian country, with the police retaining files of policies on the harsh extra-legal treatment of dissenters, including detention without trial and the more general threats to civil liberties later to be revived 
under the Counter-Terrorist measures passed after 2000. ${ }^{14}$ The harassment of Muslim minorities then was an action replay of strategies adopted against Irish suspects decades before. It was all very incongruous in the land which treasured memories of Magna Carta and he rule of law.

It chimed in too with other manifestations of violent behaviour in British life, public and private, unfamiliar if not unknown before. There were still racial tensions in areas with black communities from the Commonwealth which were to explode in riots and conflict with the police in Liverpool, Tottenham and other places in the eighties. The Wilson government responded constructively with the Race Relations Board being set up in 1976 while a think-tank, the Runnymede Trusts monitored acts of discrimination against coloured ethnic minorities in the law courts and the workplace, but tension remained. Football supporters had become increasingly aggressive since England's World Cup victory in 1966, and mob violence and gang warfare were a regular feature of town life on Saturday afternoons, terrifying for ordinary citizens who lived in the neighbourhood. Traditional local derbies such as Liverpool and Everton in Liverpool and the religious prejudices behind Rangers and Celtic 'Old Firm' clashes in Glasgow were particularly frightening. The English were frightening visitors in other countries too when their teams played away. It was with much relief that continental Europeans noted that the defeat of England by Poland kept them out of the 1974 World Cup finals. Nor was life necessarily safer behind the closed doors of home. The police recorded a rising toll of cases of domestic violence - 89,599 in 1974 alone - including a growing tally of rape and wife-battering cases. Women's Refuges were set up in many cities for protection, while Victim Support (a voluntary movement of sympathizers) provided psychological comfort. Britain seemed a more uncomfortable place in which to live a normal life. People looked back nostalgically to the comforting stereotypes of the neighbourliness and warmth of the People's War when the communal patriotic 'Dunkirk Spirit' had seemed to prevail. One profession that suffered unduly in this abrasive new atmosphere, was the police. The old image of the friendly village constable, the 'Bobby on the beat' celebrated in the television series 'Dixon of Dock Green' (and used with political success by Jim Callaghan as parliamentary spokesman for the Police Federation) was giving way, not only in Northern Ireland, to a far more abrasive relationship between police and public. Academics called the 1970s 'the golden age of Criminology'. ${ }^{15}$ It was a dubious accolade.

\section{The Renewal}

This gloomy saga of conflict, decline and aggression would appear to have made Britain ripe for major social confrontation on the lines of Les Evenements in France in 1968. Yet in fact it did not happen and many of the consequences were benign. Even with the sharp political confrontations generated in the Thatcher regime in the eighties, the United Kingdom survived and in the later nineties appeared to prosper. A major factor was that, contrary to Roy Jenkins' pessimistic forebodings, the centre broadly did hold and the fabric of society held secure, just about and with disturbing crises such as the year-long miners' crisis of 1984 - 5. It could certainly be said that the reports from the economic messengers were too gloomy. Thus, after the IMF crisis talks in the autumn of 1976 it emerged that the Treasury forecasts about the balance of payments and the Public Sector Borrowing Requirement ( $£ 8.5 \mathrm{bn}$. In $1976-7$ not the $£ 10.5 \mathrm{bn}$. forecast) were seriously wrong and offered a highly distorted account of the state of the country's finances. 
Britain was to eliminate its current account deficit in 1977 (Sod-off Day Denis Healey called it) before the IMF loan even took effect. ${ }^{16}$ The middle years of the Callaghan government in $1977-8$, when the pound recovered and the balance of trade became stronger, proved a portent of happier tidings ahead, if only industrial conflict could somehow be prevented. Consumer affluence generally improved as shown by the purchase of consumer goods such as cars and the rapidly growing number of holidays spent on continental Europe. Without lapsing into the frivolity of the so-called 'swinging sixties' and 'permissiveness' of the sixties, much of the population seemed reasonably content with their lot. In the world of culture and the arts, in its films, drama and searching television documentaries like 'Kathy Come Home', Britain seemed as creative as ever. It retained its dominance in pop music and popular fashion. In the Sixties and Seventies, British groups won the Eurovision song contest. The Beatles and the Rolling Stones still captivated the young all over the world, even if the most celebrated pop group in seventies Britain were the Swedish group Abba - though even they won fame with victory with the imperishable lyrics of 'Waterloo' at the song contest in Brighton in 1974.

23 Britain still scored heavily in the world of soft power. The decade was a flourishing one for Britain's universities, still benefiting from the stimulus of the Robbins report in the previous decade, with a much larger cohort of young people (women especially) attending higher education, newer universities such as York, Warwick and Sussex making impressive progress and many brilliant achievements for British scientific research groups. Further, university education was still totally free, with substantial maintenance grants to support less affluent students. For more mature or part-time students, the Open University, that brilliantly innovative experiment in distance learning set up under Harold Wilson's administration mainly by Jennie Lee, Nye Bevan's widow, ${ }^{17}$ entered upon a glorious period. Those who took part in lecturing to its summer schools (like the present writer) found it an inspirational experience. Lifelong learning for many housewives and others was indeed now a reality.

It was not only a decade with greater opportunity but with enough of the old welfare egalitarianism to nullify the injustices of Britain's deeply ingrained class system. One of the striking features of the seventies is that it marked a peak in egalitarianism before things fell away under the social injustices of the Thatcher era. The obscene contrast in the eighties of young men sleeping rough overnight in the malls and shop doorways of London while mindless 'yuppies' in business cashed in on the lower taxes, deregulation and hedonism symbolised by the 'Big Bang' on London's stock exchange in 1986, was not evident in the seventies. A notable document was the report of the Diamond Commission, The Royal Commission on the Distribution of Income and Wealth in Britain, whose findings appeared between 1975 and 1979. It benefited from the membership of distinguished progressive economists like Sir Henry Phelps Brown and Richard Layard. The result was to show that the share of the before-tax distribution of the wealth of the top $10 \%$ had fallen from nearly $30 \%$ in 1959 to $26.6 \%$. By contrast the $20 \%$ of the poorest households which had claimed only 0.9 of the 'original income' rose through welfare benefits and other supplementary assistance to a 'final income' share of $9.0 \%{ }^{18}$ The value of the 'social wage' was underlined for those whose earning capacity had suffered through illness, injury or unemployment. The Commission concluded that the consequence of taxes and social benefits had achieved 'a substantial redistribution towards equality'. Decades later the authors of The Spirit Level would point to the 
seventies as a rare time when Britain moved towards becoming a fairer, more socially just society. ${ }^{19}$ It never happened again.

A major reason why these positive developments occurred was because of some at least of the political leaders that this allegedly declining old regime threw up. Heath, a difficult lonely personality, had the vision and idealism, to get his reluctant insular nation to enter the European Economic Community, a major transformation of our history. He also brought a more liberal perspective to the problems of Northern Ireland. Wilson and Callaghan look much stronger in retrospect by comparison with what followed, as does their intellectually and physically tough Chancellor, Denis Healey. The Oxford historian Ross McKibbin wrote a famous article in The London Review of Books in 1991 entitled 'Homage to Wilson and Callaghan' along these lines. ${ }^{20}$ The industrial troubles of the seventies would have taken a far more violent turn had Britain been under the abrasive leadership of Margaret Thatcher and the economy functioned less well. Wilson was not a healthy man when he became prime minister again in March 1974 and there was fear of Alzheimer's. He did not anticipate his victory and apparently was disappointed when it came. But his 'social contract' had some tranquillizing effects while his confirmation of Britain's membership of the European community through a referendum was in its way a triumph as great as Heath's. He certainly handled that episode with far more skill and aplomb than David Cameron in his ill-fated campaign in June 2016. Callaghan, a calm, moderate man who comfortably dominated the new opposition leader, Margaret Thatcher, in 1976 - 9 and ended his premiership more popular than when he began (a very rare achievement) commanded national confidence, and, until a series of major tactical blunders in his final months ('Crisis, what crisis?') showed much tactical skill in conducing operations. He handled a Cabinet of prima donnas (including the perfidious Tony Benn) most adroitly, he took important new initiatives in domestic policy especially on the issue of standards in state education, and won international prestige through acting as an effective honest broker between the US president Jimmy Carter, and the German Chancellor Helmut Schmidt. The 1978 Camp David Agreement that he negotiated for Carter between President Sadat of Egypt and Menachem Begin of Israel in 1978 was a remarkable diplomatic achievement. ${ }^{21}$ Callaghan could also move on in his judgements of events. Long a fairly Eurosceptic politician, he became an important European figure, helped by his personal friendships with Schmidt and the French president Giscard d'Estaing. Towards the end of his premiership he was interested in Britain's possible involvement in the European Rate Mechanism. Callaghan and Harold Wilson helped to keep Britain an orderly country whose institutions did not cave in and whose social fabric remained relatively stable. As in the old wartime slogan, it was 'Keep Calm and Carry On'.

It should also be said that some aspects of challenge in the seventies were portents of future progress for this country. This particularly applies to women two themes that occasioned much debate at the time - feminism and Celtic nationalism. British women had not moved on from their traditional unambitious role earlier on, despite the flamboyance of the 'swinging sixties'. Young women remained fairly conventional in their social and moral attitudes (including pre-marital sex), despite the frisson they caused amongst young men with their miniskirts and absorption in pop culture. The seventies was different. Works such as Germaine Greer's Female Eunuch (1970) and the publishing house 'Virago' opened up new world of female self-expression and a more critical attitude to the traditional limited horizons bred in young British females almost from birth. Journalists like Jill Tweedie and others on the Guardian's Women's Page became apostles 
of a more adventurous, rebellious way of life. A major stimulus was the extension of higher education with women entering universities and colleges in far greater numbers, indeed coming in time to provide a majority of Britain's students. All Oxford and Cambridge's colleges would now admit women. It would take a long time for glass and other ceilings to be destroyed in women's access to major posts in business and the professions, but progress was made in the seventies. Labour governments also helped with the 1970 Equal Pay Act, and the Sex Discrimination Act of 1975. On a more sombre note, the Domestic Violence and Matrimonial Proceedings Act of 1976 gave women greater protection against violent husbands or partners. Here the tension and challenge of the seventies was clearly the result of progressive, egalitarian change which removed, at least in part, the shackles, professional and personal, which had for so long blighted women's lives. Divorce went up but so did opportunity.

Celtic nationalism was another novelty with major implications for the future. In the later sixties, the Scottish Nationalist Party and the Welsh nationalist Plaid Cymru (mainly through the Welsh-language movement) as significant political factors for the first time, but they had made little progress in the 1970 general election against the dominant Labour Party. ${ }^{22}$ The issue of Celtic nationalism or devolution then made a major advance with the 1973 Kilbrandon Commission's report which called for an elected Scottish parliament with primary legislative powers and an elected Welsh Assembly with only executive powers. The Labour government's minority position in the Commons meant that it was forced to proceed with schemes for Scottish and Welsh devolution from 1976 onwards, at first in a combined bill then in two separate measures. They were taken through the Commons by Michael Foot, an old Bevanite centralizer now converted to devolution in his late years. The English majority of Labour MPs remained either apathetic or openly hostile. In the end, referendums were held in both Scotland and Wales on 1 March 1979. Wales with no tradition of unified citizenship and long bound up with England, had little passion for devolution then and it was defeated by a vote of around four to one. In Scotland devolution was passed but with an insufficient majority of electors backing it. But it was a major portent for the future, even so. Devolution remained on the political agenda during the years of inflexible Unionism of Mrs. Thatcher that followed. In 1999 both Scottish devolution (by large majority) and Welsh devolution (by a tiny margin) had gone through and new legislatures were set up in Edinburgh and Cardiff.

The implications of this were controversial. Many feared that piecemeal devolutions would unravel the historic Union of the United Kingdom, and fears multiplied with the progress of the SNP from 2007 onwards which led to a referendum on Scottish independence which failed. A federal state at least seemed possible. But it was clear, too, that in both Scotland and Wales devolution had a liberating, democratizing effect. In Scotland, it inspired a sense of dynamism in civil society, combined with a positive view on immigration and union with Europe. In Wales, the culture and language flourished, though the economy did not. The blonde Welsh-speaking soubrette, Cerys Matthews of Catatonia, sang that 'every morning I wake up and thank the Lord I'm Welsh'. On balance the growth of Celtic nationalism, like feminism, looks like a positive portent of change that invigorated marginalised parts of the United Kingdom, making it less centralised and simply less dominated by England. In 2016 it was a saga yet unfinished. that evokes some regretful nostalgia after the Brexit referendum in June 2016, was in 
relation to Europe. This was truly a historic and fundamental change. The US Secretary of State, Dean Rusk had famously observed in 1960 that Britain had lost an empire but was still seeking a role. That was still true in 1970 with two British applications to join the EEC rebuffed by President de Gaulle, the Commonwealth manifestly less central to Britain's needs, and Heath, the new prime minister, far less concerned with building up the 'special relationship', so-called, with the United States. Heath introduced a quite new momentum. He was an enthusiastic European, coming from Kent close to France and with powerful memories of service in the war, and the years of peace that resulted. He began serious talks about access to Europe and its common market in 1971. This time he confronted not the stern resistance of President de Gaulle, but a far more emollient French president, Georges Pompidou. They had a major breakthrough meeting in Paris on 20 - 21 May 1971, which survived even Heath's dreadful French. There were tricky discussions about food imports from Commonwealth countries, the common fisheries policy and British budgetary contributions to sustain the Common Agricultural Plan to help French and German farmers. The underlying Monnet-inspired idea of 'ever closer union' politically was wisely pushed off centre-stage. In October 1972, the deed was done when the Commons agreed to entry with a majority of 112. Nearly all the Conservatives, save for a few die-hards like Enoch Powell, supported it, as did the great mass of business and the newspapers. Labour was deeply riven, but 67 Labour MPs, headed by Roy Jenkins and also including other prominent figures like John Smith and Cledwyn Hughes voted with the government, while another 20 abstained. On 1 January 1973, British became officially Europeans, even if with only modified rapture. Heath presented it as the answer to Britain's endemic economic problems, but many others remained sceptics.

The real problems of reconciling the British with Europe, the land mass only twenty miles away from Beachy Head, came in 1974 when Labour and Harold Wilson returned to power. The party had been disunited at the time of Heath's negotiations and indeed had officially voted against British membership in 1972. There were many on the left who saw it as a free-market capitalist club whose financial policies were incompatible with democratic socialism. Many too, from Enoch Powell on the right to Tony Benn and Michael Foot on the left saw European membership as an invasion of British sovereignty, the supremacy of parliament and the primacy of the British common law. Wilson, who was agnostic on the whole European question but desperate to preserve party unity on the matter, determined the final strategy. This was to call for the first time a nationwide referendum on membership of Europe, preceded by a purported renegotiation of the terms agreed, with Cabinet ministers free to campaign on either side of the issue. Callaghan's deft hands were used for the renegotiation. While most of the new decisions were little more than cosmetic, he was able to claim achievements over the British contributions to the European budget and the admission of Commonwealth products like Canadian and Australian meat and New Zealand butter, in a very unsentimental but business-like way. No Gaitskellite rhetoric about the Dardanelles and Vimy Ridge here, nor Callaghanite emphasis on 'the language of Chaucer and Milton'. The European negotiators agreed to phase down contributions for countries suffering temporary balance of payments problems. A regional fund was also set up to assist areas like Callaghan's own Wales. The referendum campaign and was tranquil and free from bitterness in the main. There was much financial support from pro-Europe banks and business groups. Unlike 2016, there was cross-party collaboration in the campaign, with Heath and Jenkins cheerfully sharing platforms, and Foot speaking alongside his friend Enoch Powell. 
With a background of solid support, membership of Europe easily went through. It was a two to one majority, with around 17 million voting for membership and around 8 million against. The voters accepted the result with equanimity - after all the European world was far more familiar now with millions of British people taking holidays on the continent, notably France, Italy and ex-Franco Spain. Young people, especially students, were growing up in a multi-cultural world, enjoying claret and cappuccino and riding Lambrettas, with European fashions, films, food and football part of normal day-to-day experience. There had not been a proper debate. The political aims of the EEC were not considered at all, not even British entry into the European parliament, which finally happened in 1979. There were constant grumbles about French farmers, Spanish fishermen and Germans of all shades. Immigration was not an issue. There was not much affection on display, especially within the Labour Party whose 1979 manifesto was opposed to membership. It was no union of hearts. British Euroscepticism remained powerful and never went away. But it was also a colossal breakthrough, in terms of trade, political associations and perhaps in national psychology. The Battle of Britain insularity of 1940 vintage had gone. At last Britain had found a role, which seemingly would determine its future for the rest of time.

Entry into the European Community was the climax of a relatively trouble-free experience for Britain in the wider world. Britain fought no wars (perhaps fortunately since most of its troops were now used in strike-breaking or were stationed in Northern Ireland). Polaris submarines were renewed with Callaghan's Chevaline programme in 1979 but there was no prospect of their ever being used in anger. CND was subdued. The prospect of military action against Ian Smith's unilateral declaration of independence in Rhodesia, which would have been extraordinarily delicate against Britain's 'kith and kin', faded away. In 1979 one of Mrs. Thatcher's first actions was to negotiate a settlement in Rhodesia which was transformed into an independent country, Zimbabwe, under the erstwhile Marxist president, Robert Mugabe. A potential crisis with Argentina over the Falklands (the Malvinas to the Argentines) was skilfully negotiated away by Callaghan as Foreign Secretary: he did at least keep a Royal navy vessel, the Endurance, in Falklands waters flying the white ensign, whereas Mrs. Thatcher took one away and had to fight a costly war in consequence..$^{23}$ Callaghan also resisted American pressure to intervene over Belize. The British, tormented at home by manifold problems, buttressed overseas by having joined Europe, freed from the remnants of empire, seemed content with a more withdrawn post-colonial role. Foreign crises were occasionally to afflict the nation - Suez in the fifties, Iraq in the new century, under both Conservatives and Labour. But the United Kingdom, whatever its domestic travails, rejoiced in its international position as a land at peace.

This tranquil view is not a bad requiem on the stormy seventies. The land was tortured by innumerable crises during that decade. Some like Northern Ireland dragged on for more than two decades. But it had its elements of stability and progress. In the future, many would hail Margaret Thatcher as the pilot who weathered the storms and restored order and national self-confidence. In some ways she undoubtedly did so, though at grave social cost. She also converted New Labour to many of her essential principles. But the decade of Heath, Wilson and Callaghan, had its own successes, as an exercise in survival and, in the case of Europe, brilliant vision. Perhaps the so-called dark ages when the lights went out veiled a process of readjustment and renewal. Britain remained a land if not of glory at least of hope. 
Kenneth Morgan est universitaire depuis 1958. Il est auteur d'une vingtaine de monographies, notamment quatre biographies des figures politiques de premier plan: David Lloyd George, Keir Hardie, James Callaghan et Michael Foot, et de fresques ambitieuses telles que A People's Peace: La Grande-Bretagne depuis 1945. Soucieux du rayonnement de la recherche historique, il intervient régulièrement dans les différents médias.

\section{NOTES}

1. Kathleen Burk and Alec Cairncross, Goodbye Great Britain (Yale University Press, 1992).

2. See Kenneth O. Morgan, Michael Foot: a Life (Oxford University Press) chapter 8.

3. Tony Benn, Conflicts of Interest: Diaries 1977 - 80 Hutchinson, 1990), p. 448 - 9 (30 January 1979).

4. Robert Taylor, The Trade Union Question in British Politics (Blackwell, Oxford, 1993), appendix 5, p. 379.

5. Mrs. Thatcher, Speech to Conservative Party conference, 1985.

6. Andy Beckett, When the Lights went out: Britain in the Seventies (Faber and Faber, London, 2009), pp. $274 \mathrm{ff}$.

7. See Edmund Dell, A Hard Pounding. Politics and Economic Crisis,1974 - 76 (Oxford University Press, 1990).

8. Personal information from the late Lord Callaghan, Lord Healey and Peter Jay.

9. Douglas Jay, Sterling (London, Sidgwick and Jackson, 1985), pp. 162 - 3.

10. Coined in The Economist, 13 February1954.

11. Becket, op.cit., pp. $279 \mathrm{ff}$.

12. The Economist, 2 June 1979.

13. See James Callaghan, A House Divided. The Dilemma of Northern Ireland (Collins, London, 1973); Paul Bew, Ireland: the Politics of Enmity 1789 - 2006 (Oxford Univiersity Press, 2007, pp. $502 \mathrm{ff}$.

14. See Kenneth O. Morgan, 'The Political and Parliamentary Aspects of Pre-trial Detention in the United Kingdom since 2000', in Marion del Bove and Fabrice Mourlon (eds.), Pre-Trial Detention in $19^{\text {th }}$ and $20^{\text {th }}$ Century Common Law and Civil Law Systems (Cambridge Scholars Publishing, Newcastle-on-Tyne, 2014), pp. $13 \mathrm{ff}$.

15. Paul Rock, A History of British Criminology (Dartmouth Publishing, London, 1994).

16. Kenneth O. Morgan, Callaghan a Life (Oxford University Press, Oxford, 1997), p. 552.

17. Patricia Hollins, Jennie Lee: a Life_(Oxford University Press, Oxford, 1997), pp. 327 ff.,

18. Royal Commission on the Distribution of Income and Wealth in Britain. Reports 3 and 4 (Cmnd. 6838 and Cmnd. 6626); Reports 5 and 6 (Cmnd. 6999 and Cmnd. 7175), 1977 - 8.

19. Richard Wilkinson and Kate Pickett, The Spirit Level. Why Equality is better for Everyone (Penguin, 2010). The case for greater equality is powerfully argued in Joseph Stiglitz, The Price of Inequality and The Great Divide_(Penguin, London, 2015). 
20. London Review of Books, 24 October 1991; also see Michael Artis and David Cobham (eds.), Labour's Economic Policies 1974 - 1979 (Manchester University Press, 1991) which compares Labour's economic record very favourably with that of the Thatcher period.

21. Kenneth O. Morgan, Callaghan, pp. 608 - 9, especially Carter- Callaghan telexed conversation, 15 January 1978.

22. Kenneth O. Morgan, 'From Unionism to Devolution', in Anne-Marie Motard (ed.), Devolution, Identites et Nationalismes (Presses Universitaires de la Mediterrannee, Montpellier, 2009), pp. $77 f f$.

23. Private information from Lord Callaghan; also see Kenneth O. Morgan, Callaghan, pp.460-462.

\section{ABSTRACTS}

In popular recollection, the 1970s have gone down as the dark ages, Britain's gloomiest period since the second world war, set between Harold Wilson's 'swinging sixties' and Margaret Thatcher's divisive eighties. Forty years on, it is appropriate for the historian to examine how valid these depressing verdicts on the United Kingdom really were. Were the dark ages an exaggerated fabrication of excited journalists and ill-disposed foreigners? Or did the seventies uncover something fundamentally wrong about this ancient people which survives to diminish its authority and restrict its vision down to the present day?

Dans la mémoire collective, les années 1970 constituent la période la plus sombre de l'histoire contemporaine britannique depuis la seconde guerre mondiale, coincées entre les "swinging 60's d'Harold Wilson et les années 1980 "clivantes" de Margaret Thatcher. Avec le recul de quatre décennies il est temps pour l'historien de réévaluer le fondement de ces verdicts pessimistes.

\section{INDEX}

Mots-clés: Années 1970, historiographie, crise, pessimisme, déclinisme

Keywords: 1970s, historiography, crisis, pessimism, declinism

\section{AUTHOR}

\section{KENNETH O. MORGAN}

Independent Scholar, United Kingdom 